\title{
PENGARUH METODE PEMBELAJARAN DOUBLE LOOP PROBLEM SOLVING (DLPS) TERHADAP HASIL BELAJAR IPS SISWA KELAS VIII SMP NEGERI 3 MATARAM TAHUN PELAJARAN 2015-2016
}

\author{
${ }^{1}$ Mas'ad, ${ }^{2}$ Muhammad Nizaar, ${ }^{3}$ Agus Merdeka Putra \\ ${ }^{1,2,3}$ Dosen Program Studi Pendidikan Geografi, Universitas Muhammadiyah Mataram \\ Email : nijadompu542@gmail.com
}

\begin{abstract}
ABSTRAK
Tujuan penelitian ini adalah untuk mengetahui pengaruh penggunaan strategi Double Loop Problem Solving (DLPS) terhadap hasil belajar siswa. Metode DLPS adalah variasi dari pembelajaran dengan pemecahan masalah dengan penekanan pada pencarian kausal (penyebab) utama dari timbulnya masalah. Rancangan penelitian yang digunakan adalah kuasi eksperimen dengan populasi penelitian yaitu siswa kelas VIII SMP Negeri 3 Mataram semester ganjil tahun pelajaran 2015/2016. Sedangkan sampel dalam penelitian ini adalah kelas $\mathrm{VIII}_{1}$ sebagai kelas eksperimen dengan jumlah siswa 21 orang dan kelas $\mathrm{VIII}_{3}$ sebagai kelas kontrol dengan jumlah siswa 24 orang. Teknik pengumpulan data dilakukan menggunakan metode tes obyektif berbentuk pilihan ganda yang diberikan sebelum dan setelah rangkaian kegiatan pembelajaran dilakukan yang kemudian dilakukan uji normalitas, uji homogenitas, dan uji hipotesis. Berdasarkan hasil analisis data diperoleh bahwa nilai signifikan tes akhir dari kedua kelas lebih kecil dari 0,05 yaitu sebesar 0,016 yang berarti bahwa $\mathrm{H}_{\mathrm{a}}$ diterima dan $\mathrm{H}_{0}$ ditolak, artinya terdapat pengaruh metode pembelajaran DLPS terhadap hasil belajar IPS siswa kelas VIII SMP Negeri 3 Mataram Tahun Pelajaran 2015-2016.
\end{abstract}

Kata Kunci : Metode DLPS (Double Loop Problem Solving), Hasil Belajar

\section{PENDAHULUAN}

Pembelajaran adalah proses interaksi peserta didik dengan pendidik dan sumber belajar pada sebuah lingkungan belajar. Penggunaan strategi pembelajaran yang kurang melibatkan siswa secara aktif, terpusat pada guru, dan cenderung monoton akan dapat mempengaruhi hasil belajar siswa. Oleh karena itu, guru sebagai pengelola sistem perencanaan dan pelaksanaan pembelajaran harus dapat merancang dan menentukan strategi pembelajaran yang tepat dan efektif yang sesuai dengan tujuan atau kompetensi yang akan dicapai (Achmad, 2013: 1).

Hasil observasi yang telah dilakukan pada kelas VIII di SMP Negeri 3 Mataram menunjukkan permasalahan perencanaan dan pengelolaan pembelajaran masih dinilai kurang mampu mempengaruhi hasil belajar yang baik. Masalah utamanya berakar pada anggapan siswa tentang IPS sebagai pelajaran yang kurang menarik dan membosankan. Selama ini, proses pembelajaran seharihari di dalam kelas masih didominasi oleh guru yang memberikan informasi dan siswa yang mencatat semua materi yang diberikan sehingga sebagian besar siswa menjadi kurang tertarik untuk menyimak materi yang sedang dijelaskan. Selain itu, siswa juga enggan untuk bertanya serta mengemukakan pendapatnya terkait materi yang sedang dibahas pada saat proses pembelajaran.

Berdasarkan beberapa persoalan diatas, maka diperlukan suatu metode pembelajaran yang cocok dimana siswa tidak hanya ikut serta secara aktif dalam mengikuti kegiatan pembelajaran tetapi juga memberikan kesempatan kepada siswa untuk menumbuh kembangkan kemampuan berpikir sehingga memberikan peningkatan pada hasil belajar siswa. Peneliti menawarkan suatu alternatif solusi pembelajaran yakni dengan menerapkan metode pembelajaran double loop problem solving (DLPS).

Metode DLPS adalah variasi dari pembelajaran dengan pemecahan masalah dengan penekanan pada pencarian kausal (penyebab) utama dari timbulnya masalah. Metode DLPS banyak digunakan untuk menunjang pendekatan pembelajaran yang mengajak peserta didik untuk aktif dalam kegiatan belajar mengajar. DLPS berfokus pada pemecahan masalah yang kompleks dan tak terstruktur. Dalam metode pembelajaran ini, siswa perlu didorong untuk bekerja pada dua loop pemecahan yang berbeda, akan tetapi saling terkait.

Pada akhirnya pembelajaran dengan metode ini diharapkan dapat meninggalkan kesan yang mendalam dalam benak siswa dan menjadikannya sebagai suatu pengalaman pembelajaran yang bermakna bagi 
kehidupan mereka kedepannya sehingga berdampak pada peningkatan hasil belajar siswa.

II. KAJIAN PUSTAKA

A. Pengertian dan Ciri Metode Pembelajaran DLPS

Metode Double Loop Problem Solving (DLPS) adalah variasi dari pembelajaran dengan pemecahan masalah dengan penekanan pada pencarian kausal (penyebab) utama dari timbulnya masalah. DLPS banyak digunakan untuk menunjang pendekatan pembelajaran yang mengajak peserta didik untuk aktif dalam kegiatan belajar mengajar.

Metode DLPS juga dikenal dengan metode pengambilan keputusan. Keputusan yang diambil dalam metode ini menyangkut proses mempertimbangkan berbagai macam pilihan, yang akhirnya akan sampai pada suatu kesimpulan yang atas pilihan yang akan diadopsi. Pada saat suatu kelompok diminta untuk membuat keputusan, mereka berusaha untuk mencari konsensus, yang dalam hal ini berarti setiap partisipan paling tidak dapat menerima pilihan yang telah diambilnya.

Metode DLPS mengacu pada pemecahan masalah sebanyak dua kali atau double loop problem solving. Seperti metode pemecahan masalah yang lain, DLPS juga merupakan suatu metode pembelajaran dimana pembelajar disodorkan berupa suatu masalah untuk dipecahkan oleh peserta didik yang sebelumnya telah dibentuk dalam beberapa kelompok kecil yang dipandu oleh pendidik. Jadi, DLPS merupakan lingkungan belajar yang di dalamnya menggunakan masalah untuk belajar, yaitu sebelum peserta didik memulai pelajaran mereka diberikan suatu masalah.

Adapun ciri utama yang terdapat dalam metode DLPS adalah pembelajarannya yang berpusat pada pemberian masalah untuk dibahas oleh peserta didik sehingga melatih peserta didik untuk berpikir dengan kreatif. Masalah tersebut dipecahkan melalui dua loop. Metode DLPS memberikan kesempatan kepada peserta didik untuk menentukan tujuan belajarnya sendiri. Para pendidik harus bisa menjadi pelatih, fasilitator, dan motivator untuk para peserta didik.

\section{B. Langkah-langkah Penyelesaian Masalah dalam Metode DLPS}

Pemecahan masalah menyangkut diambilnya suatu tindakan korektif untuk menutup kesenjangan masalah dengan menghilangkan atau memudahkan penyebab masalah. Oleh karena itu, mencapai pemecahan masalah yang tuntas diperlukan identifikasi semua penyebab dari masalah tersebut.
Metode DLPS mengakomodasi adanya perbedaan dari penyebab suatu masalah, termasuk mekanisme bagaimana sampai terjadi suatu masalah. Dalam DLPS, siswa perlu didorong untuk bekerja pada dua loop pemecahan yang berbeda, akan tetapi saling terkait.

a. Loop solusi 1 ditujukan untuk mendeteksi penyebab masalah yang paling langsung dan kemudian merancang dan menerapkan solusi sementara.

b. Loop solusi 2 berusaha untuk menemukan penyebab yang arasnya lebih tinggi,dan kemudian merancang dan mengimplementasikan solusi dari akar masalah (Huda, 2013: 303).

Adapun langkah penyelesaian masalah yang lain yang termasuk dalam kriteria DLPS yaitu:

a. Menuliskan pernyataan masalah awal,

b. mengelompokkan gejala,

c. menuliskan pernyataan masalah yang telah direvisi,

d. mengidentifikasi kausal (penyebab),

e. implementasi solusi,

f. identifikasi kausal utama,

g. menemukan pilihan solusi utama, dan

h. implementasi solusi utama.

Masalah dapat dievaluasi atas dasar tingkat kepentingannya dan tingkat kompleksitas solusinya. Kelompok siswa perlu terlibat dalam pemecahan masalah ketika masalah tersebut memang cukup penting dan tidak dapat dipecahkan oleh seorang individu. Sebaliknya, masalah yang tidak penting tidak perlu investasi dalam bentuk aktivitas pemecahan masalah secara kelompok (Huda, 2013:17).

Berdasarkan penjelasan di atas, dapat ditegaskan bahwa metode DLPS merupakan metode pembelajaran yang berpusat pada pemberian masalah yang mendorong siswa untuk bekerja pada dua loop pemecahan masalah yang berbeda namun saling terkait. Loop solusi 1 ditujukan untuk mendeteksi penyebab masalah yang paling langsung dan kemudian merancang dan menerapkan solusi sementara, sedangkan loop solusi 2 berusaha untuk menemukan penyebab yang arasnya lebih tinggi, dan kemudian merancang dan mengimplementasikan solusi dari akar masalah.

\section{Pengertian dan Jenis-Jenis Hasil Belajar}

Menurut Suprijono (2012: 27), hasil belajar merupakan perubahan perilaku secara keseluruhan bukan hanya salah satu aspek potensi kemanusiaan saja. Artinya, hasil pembelajaran yang dikategorisasi oleh para pakar pendidikan tidak dilihat secara fragmentaris atau terpisah, melainkan komprehensif. Hasil belajar juga didefinisikan sebagai perubahan yang mengakibatkan manusia berubah dalam sikap dan 
tingkah lakunya (Purwanto, 2013: 79). Berdasarkan uraian di atas, peneliti menyimpulkan bahwa hasil belajar adalah perubahan yang terjadi sebagai hasil pencapaian proses belajar mengajar dengan menggunakan metode pembelajaran DLPS.

Hasil belajar seringkali digunakan sebagai ukuran untuk mengetahui seberapa jauh seseorang menguasai bahan yang sudah diajarkan. Oleh karena itu, hasil belajar perlu dievaluasi. Evaluasi dimaksudkan sebagai cermin untuk melihat kembali apakah tujuan yang ditetapkan telah tercapai dan apakah proses belajar mengajar telah berlangsung efektif untuk memperoleh hasil belajar. Dengan kata lain, pengukuran perubahan perilaku akibat belajar akan akan mencakup pengukuran atas domain kognitif, afektif dan psikomotorik sebagai hasil belajarnya, yang dikenal dengan istilah domain hasil belajar (Purwanto, 2013: 80).

a. Hasil belajar kognitif

Menurut Krathwohl dan Anderson (2010: 35), dimensi proses kognitif berisikan enam kategori: Mengingat, Memahami, Mangaplikasikan, Menganalisis, Mengevaluasi, dan Mencipta. Memahami dianggap merupakan tingkatan kognisi yang lebih kompleks dibandingkanmengingat; mengaplikasikan diyakini lebih kompleks secara kognitif daripada memahami, dan seterusnya.

b. Hasil belajar afektif

Bidang afektif berkenaan dengan sikap dan nilai. Tipe hasil belajar afektif tampak pada siswa dalam berbagai tingkah laku seperti atensi/perhatian terhadap pelajaran, disiplin, motivasi belajar, menghargai guru dan teman sekelas, kebiasaan belajar, dan lain-lain. Ada beberapa tingkatan bidang afektif sebagai tujuan dan tipe hasil belajar. Tingkatan tersebut dimulai dari tingkat yang sederhana sampai tingkatan yang kompleks (Sudjana, 2013:32).

1) Receiving/attending, yakni semacam kepekaan dalam menerima rangsangan dari luar yang datang pada siswa.

2) Responding, yakni reaksi yang diberikan seseorang terhadap rangsangan yang datang dari luar.

3) Valuing, yakni berkenaan dengan nilai dan kepercayaan terhadap gejala atau rangsangan tadi.

4) Organisasi, yakni pengembangan nilai ke satu sistem organisasi, termasuk menentukan hubungan satu nilai dengan nilai lain dan kemantapan.

5) Karakteristik nilai, yakni keterpaduan dari semua sistem nilai yang telah dimiliki seseorang, yang mempengaruhi pola kepribadian dan tingkah lakunya.

c. Hasil belajar psikomotor

Hasil belajar bidang psikomotor tampak dalam bentuk keterampilan (skill) bertindak individu. Ada 6 tingkatan keterampilan psikomotor yakni (Sudjana, 2013: 33):

1) Gerakan refleks (keterampilan pada gerakan yang tidak sadar).

2) Keterampilan pada gerakan-gerakan dasar.

3) Kemampuan perseptual termasuk di dalamnya membedakan visual, membedakan auditif motorik dan lain-lain.

4) Kemampuan di bidang fisik, misalnya kekuatan, kehamonisan, ketepatan.

5) Gerakan-gerakan skill, mulai dari keterampilan sederhana sampai keterampilan yang kompleks.

6) Kemampuan yang berkenaan dengan nondecursive komunikasi seperti gerakan akspresif dan interpretatif.

\section{METODE PENELITIAN}

Rancangan penelitian yang digunakan adalah kuasi eksperimen. Menurut Setyosari (2013: 125), pada penelitian kuasi eksperimen peneliti tidak dapat mengontrol sepenuhnya variabel-variabel luar yang mempengaruhi pelaksanaan eksperimen. Penelitian yang digunakan termasuk ke dalam kelompok nonekuivalen (pretest-posttest) control group design. Dalam desain ini sampel dibagi menjadi dua kelompok yaitu kelompok pertama sebagai kelas eksperimen yang diberikan perlakuan dengan metode DLPS dan kelompok kedua sebagai kelas kontrol.

Populasi penelitian ini yaitu siswa kelas VIII SMP Negeri 3 Mataram semester ganjil tahun pelajaran $2015 / 2016$. Adapun sampel dalam penelitian ini adalah kelas $\mathrm{VIII}_{1}$ sebagai kelas eksperimen dengan jumlah siswa 21 orang dan kelas $\mathrm{VIII}_{3}$ sebagai kelas kontrol dengan jumlah siswa 24 orang. Pengambilan sampel dilakukan dengan menggunakan teknik purposive sampling, dimana pengambilan sampel dilakukan karena adanya alasan tertentu yakni dikarenakan kedua kelas tersebut yang diijinkan oleh guru mata pelajaran untuk diteliti. Teknik pengumpulan data dilakukan menggunakan metode tes. Tes yang digunakan adalah tes obyektif berbentuk pilihan ganda yang diberikan sebelum dan setelah rangkaian kegiatan pembelajaran dilakukan.

Sebelum data yang diperoleh dianalisis, terlebih dahulu perlu dilakukan uji normalitas, uji homogenitas, dan uji hipotesis.

a. Uji Normalitas

Uji normalitas dilakukan untuk mengetahui normal tidaknya distribusi data. Uji normalitas dapat dicari dengan menggunakan persamaan Chi-kuadrat. 


$$
\chi^{2}=\sum_{i=1}^{k} \frac{\left(f_{o}-f_{e}\right)^{2}}{f_{e}}
$$

Jika nilai uji $\chi^{2}<\chi_{\text {tabel }}^{2}$ maka data tersebut berdistribusi normal. Berdasarkan uji normalitas pada kelas eksperimen dan kelas kontrol didapatkan bahwa data pada kedua kelas tersebut terdistribusi normal.

b. Uji Homogenitas

Uji homogenitas dimaksudkan untuk mengetahui apakah sampel berasal dari populasi yang homogen. Artinya kemampuan awal siswa di dalam penelitian ini diasumsikan sama. Uji homogenitas dilakukan dengan menggunakan uji -,:

Kriteria pengujian adalah sebagai berikut:

1) Jika $F_{\text {hitung }}>F_{\text {tabel }}$, data tidak homogen,

2) Jika $F_{\text {hitung }} \leq F_{\text {tabel }}$, data homogen.

Berdasarkan uji homogenitas sampel kelas eksperimen dan kelas kontrol didapatkan nilai $F_{\text {hitung }}$ $\leq \mathrm{F}_{\text {tabel }}$ sehingga dikatakan homogen.

c. Uji Hipotesis (Uji-t)

Untuk mengetahui pengaruh penggunaan strategi Double Loop Problem Solving (DLPS) terhadap hasil belajar siswa, maka data tes akhir (objektif) akan dianalisis dengan menggunakan rumust-test yang secara umum pola peneliti dilakukan terhadap 2 kelompok, yang satu kelompok eksperimen (yang dikenai perlakuan) dan kelompok kontrol atau kelompok pembanding yang tidak dikenai. Adapun rumus $t$-test tersebut sebagai berikut:

$$
\frac{t_{\text {hitung }}=}{\sqrt{\frac{s_{1}^{2}}{n_{1}}+\frac{s_{2}^{2}}{n_{1}}-2 r\left(\frac{s_{1}}{\sqrt{n_{1}}}\right)+\left(\frac{s_{2}}{\sqrt{n_{2}}}\right)}}
$$

Hasil uji-t dikonsultasikan dengant table dengan $\mathrm{db}=$ $\left(n_{1}+n_{2}-2\right)$ pada taraf kesalahan $5 \%$, dengan kriteria pengujian jika $-\mathrm{t}_{\text {tabel }} \leq \mathrm{t}$ hitung $\leq+\mathrm{t}$ table maka $H_{0}$ diterima dan $\mathrm{H}_{a}$ ditolak (Riduwan, 2010: 52).

\section{HASIL PENELITIAN}

A. Uji Prasyarat Analisis

1. Uji normalitas

Uji normalitas dilakukan dengan bantuan program SPSS 18 dengan taraf sigifikan 5\%. Adapun interpretasi data yang diperoleh sebagai berikut.

\begin{tabular}{lcc}
\multicolumn{3}{c}{ Tabel 1. Hasil Uji Normalitas } \\
\hline \multicolumn{1}{c}{ Kelas } & $\begin{array}{c}\text { Asymp. } \\
\text { Sig. }\end{array}$ & Kesimpulan \\
\hline Eksperimen & 0,293 & Normal \\
Kontrol & 0,766 & Normal \\
\hline
\end{tabular}

Tabel di atas menunjukkan bahwa data terdistribusi normal.

\section{Uji Homogenitas}

Uji homogenitas dilakukan dengan menggunakan uji- $F$ dengan taraf signifikansi $5 \%$. Hasil uji homogenitas disajikan dalam tabel berikut.

Tabel 2. Hasil Uji Homogenitas

\begin{tabular}{cccc}
\hline \multicolumn{1}{c}{ Kelas } & $\mathbf{F}_{\text {hitung }}$ & $\mathbf{F}_{\text {tabel }}$ & Kesimpulan \\
\hline $\begin{array}{l}\text { Eksperimen } \\
\text { Kontrol }\end{array}$ & 1,21 & 2,04 & Homogen \\
\hline
\end{tabular}

Berdasarkan nilai yang tertera pada tabel di atas, menunjukkan bahwa nilai $F_{\text {hitung }}<F_{\text {tabel }}$ sehingga disimpulkan bahwa kedua sampel berasal dari populasi yang homogen.

3. Pengujian Hipotesis

Data hasil belajar siswa yang diperoleh dianalisis dengan menggunakan uji $t$-test polled varians dengan menggunakan bantuan program SPSS 18. Adapun hasil analisis uji-t ditunjukkan pada tabel berikut.

Tabel 3. Hasil Analisis Uji Hipotesis Hasil Belajar Siswa Kelas VIII SMPN 3 Mataram

\begin{tabular}{lccccc}
\hline \multicolumn{1}{c}{ Kelas } & $\begin{array}{c}\text { Jumlah Siswa } \\
(\mathbf{n})\end{array}$ & $\begin{array}{c}\text { Rata- } \\
\text { rata }\end{array}$ & Varians & $\begin{array}{c}\text { Sig. (2- } \\
\text { tailed) }\end{array}$ & Kesimpulan \\
\hline Eksperimen & 21 & 75,48 & 49,76 & & \\
Kontrol & 24 & 70,42 & 41,12 & 0,016 & $\mathrm{H}_{\mathrm{a}}$ Diterima \\
\hline
\end{tabular}

Tabel di atas menunjukkan bahwa nilai signifikan tes akhir dari kedua kelas tersebut lebih kecil dari 0,05. Hal ini berarti bahwa $\mathrm{H}_{\mathrm{a}}$ diterima dan $\mathrm{H}_{0}$ ditolak, artinya terdapat pengaruh metode DLPS terhadap hasil belajar siswa.

Berdasarkan hasil analisis data akhir pengujian hipotesis dengan menggunakan bantuan program SPSS 18 pada taraf signifikan 0,05 diperoleh nilai signifikan sebesar 0,016. Hasil tersebut menunjukkan bahwa nilai signifikan yang diperoleh lebih kecil dari 0,05 sehingga hipotesis alternatif diterima dan hipotesis nol ditolak.

Pada pembelajaran dengan metode DLPS siswa belajar untuk menemukan konsep pengetahuannya sendiri sehingga pengetahuan yang diperoleh lebih kuat melekat dalam ingatan mereka. Dengan kuatnya informasi yang melekat pada memori siswa, tentu akan berdampak pula terhadap perolehan hasil belajar siswa. 


\section{KESIMPULAN DAN SARAN}

Berdasarkan hasil analisis data dan pembahasan, diperoleh bahwa nilai signifikan tes akhir dari kedua kelas lebih kecil dari 0,05 yaitu sebesar 0,016. Hal ini berarti bahwa $\mathrm{H}_{\mathrm{a}}$ diterima dan $\mathrm{H}_{0}$ ditolak, artinya terdapat pengaruh metode pembelajaran DLPS terhadap hasil belajar IPS siswa kelas VIII SMP Negeri 3 Mataram Tahun Pelajaran 2015-2016.

Adapun saran-saran yang dapat diberikan terkait dengan pelaksanaan penelitian ini diantaranya yaitu:

a. Alokasi waktu diatur sebaik mungkin sehingga pembelajaran dapat berlangsung secara optimal, kadangkala guru tidak mampu mengatur waktu karena menunggu proses analasisi siswa yang terlalu lama;

b. Karakteristik dari siswa perlu diidentifikasi terlebih karena anak yang tidak biasa berpikir akan susah mengikuti proses belajar DLPS, biasanya anak yang suka mengaktifkan psikomotoriknya kurang menyenangi metode ini.

\section{DAFTAR REFERENSI}

Achmad. 2013. Perbandingan Penerapan Model Pembelajaran Think Pair Share (TPS) dengan Think Talk Write (TTW) Terhadap Hasil Belajar Geografi Siswa Kelas X SMAN 01 Bululawang. Jurnal Program Studi Pendidikan Geografi. Diakses pada tanggal 12 Agustus 2015.

Anderson, Lorin W. dan David R. Krathwoh. 2010. Kerangka Landasan untuk Pembelajaran, Pengajaran, dan Asesmen. Yogyakarta: Pustaka Pelajar.

Anonim. Diakses dari http:// weblogask.blogspot.com pada tanggal 28 September 2015 pukul 11.00 WITA.

Indra, Pramana. 2014. Penerapan Model Double Loop Problem Solving (DLPS) dalam Upaya Meningkatkan Prestasi belajar Matematika Siswa SMP Negeri 4 Singaraja Bali. Jurnal Program Studi Pendidikan Geografi.

Suprijono, Agus. 2010. Cooperative Learning Teori dan Aplikasi Paikem. Yogyakarta: Pustaka Pelajar. 